\title{
The Effect of Different Concentrations of the Run and Stuck Bacteria (Lactobacillus fermentum, Lactobacillus delbrueckii) in Trophozoite Growth Entamoeba histolytica in Vitro
}

\author{
Zainab Farooq Shafeek ${ }^{1 *}$ and Nada Sabah Ruzzuki \\ ${ }^{1}$ University of Al-Mustansiriyah, College of Pharmacy, Clinical Laboratory, Science \\ Department, Iraq \\ ${ }^{2}$ Baghdad University, College of sciences for Women, Biology Department, Iraq \\ *Corresponding author email id:
}

Keywords

Lactobacillus

fermentum,

L.delbrueckii,

Entamoeba

histolytica.

\begin{tabular}{l}
\hline Article Info \\
\hline Accepted: \\
25 June 2016 \\
Available Online: \\
10 July 2016
\end{tabular}

A B S T R A C T

This study describes the in vitro effect Lactobacillus fermentum, L.delbrueckii in Entamoeba histolytica was isolated from stools samples of patients with (amebic dysentery) and cultivated on Lock-egg medium to which sheep serum added. Than stud the effect of different concentrations $\left(1.5 \times 10^{2}, 1.5 \times 10^{4} 1.5 \times 10^{8}\right)$ of stuck (L.fermentum, L.delbruekii), and subject to examining after $(24,28,72)$ hours of incubation, as well as to be observed the range of these concentrations' ability of the stuck and (L.fermentum, L.delbruekii) to reduce and resist the amebic.E. histolytica, additionally to note the changes in formation that parasites suffering from, during the period of treatment, Comparing with metronedizole (flagyl).The results showed the effectiveness of bacteria stuck in the inhibition proliferation of parasite growth a higher compared degree with the (L. fermentum, L.delbruekii) with the drug of metronidazole (Filagel) the treatment of effective concentrations reached to $\left(1.5 \times 10^{2}, 1.5 \times 10^{4}, 1.5 \times 10^{8}\right)$ of bacteria stuck $(46.42,88.65,97.68) \%$ respectively, after a $72 \mathrm{~h}$ incubation. While the effectiveness of the treatment reached to $(42.67,31.57,16.11) \%$ respectively, after $48 \mathrm{~h}$ incubation, while the (L. fermentum, L.delbruekii) showed less efficient compared to the treatment of metronidazole, It was noted the decomposition of the plasma membrane and the small size of amoeba from the natural state and discoloration phases with bad dye trypan blue.

\section{Introduction}

The amoebic dysentery are primitive unicellular microorganisms characterized with relatively simple life cycle, which is divided into two stages : the actively motile feeding stage (trophozoite), and the quiescent, resistant, infective stage (Cyst) (Murray et al., 2013). The infection of amoebic dysentery remains one of the most dangerous of the world's health problems and most serious intestinal diseases, especially in developing countries, so the speed and accuracy of screening for these parasites is considered the essential one in controlling the spread of mutants amoebic disease (Srivastava et al., 2005). Infection of 
ameba is spread all over the world and incidence is risen, as well, in tropical and subtropical areas, as well as with health and cultural low-lying areas (Pham et al., 2011). About $90 \%$ of people with (amebiasis) the disease is developed with them form enteric (luminal form), so dysentery is happened and the invasion of the disease in less than $10 \%$ of cases, that can be fatal, statistics showed that the number of people with the parasite are about 50 million cases, hundred thousand of them are died per year (Bauman, 2015).

Probiotics are defined as useful and effective microscopic bodies that have an effective and key role in the natural protection from the harm of pathological biologist microorganisms, used in food support for the purpose of providing the beneficial effects to human health by restoring the natural balance of (Normal flora) and reduction of diseases, especially related to the digestive system (Al-Awad et al., 2004).Thus, the treatment microscopic bodies are considered important defenses against many pathogens for many body parts, as they are characterized with the advantage by the impact of general mechanisms that determine vital boosters, which include the competition for binding sites on the intestinal surface, furthermore they participate in stimulating the immune system,and excretion of anti-materials and the prevention of pathogenicity, resist low $(\mathrm{pH})$, and resist the acidity plus the ability to layer adhesion of epithelial lining of the intestines. (Forbes et al., 2007). Lactic acid bacteria is considered, particularly Lactobacillus group of the important groups that are used in fermented food industry because of their health benefits and their ability to inhibit the growth of pathogenic bacteria to produce a lot of counter materials such as organic acids, hydrogen peroxide and bacteriocins. The components of this group is characterized that their members are homogeneous in fermentation and they are grown at temperatures probably reach at $45^{\circ} \mathrm{m}$, these bacteria are found in nature, in fermented foods and dairy products, as well as in the gastrointestinal tract, mouth and genital tract of the female human and animal (Reid et al., 2001). It is worthy to say that the effect of the antagonistic between microbiology important has a key role in (Biological control), towards many of the parasites that infect on humans and reducing their spread. The studies on the impact of lactic acid on most parasites are rare, especially concerning the parasite Entamoeba histolytica as they are one of the most intestinal parasites that are common. That is why this study was to clarify the possibility of the use of lactic acid bacteria and their stuck for prevention and reduction of incidence with parasite amoebic dysentery, additionally to be used as a treatment for this parasite

\section{Materials and Methods}

\section{Parasite collection and diagnosis of stool samples}

Sixty stool samples were collected belonging to patients of different ages, in Al- Mahmudiya General Hospital, Children's Protection Hospital (Medical City) for the period from November 2014 to March 2015 putting in sterile plastic containers, full information on each patient recorded have been codified in card information (Questionnaire) included name, age, sex, residence, profession, test results come out, the type of drugs covered by the patient in the last week, Is the patient suffering from one of the following symptoms (fever - diarrhea - bloody stand abdominal pain - weight loss).After confirmation of infection of the parasite through diagnosis of several tests, including 
macroscopic examination where it is Note stool samples in terms of (consistency) and color and the presence of blood or mucus with feces, the microscopic examination as used the method of screening Wet mounts to conduct this examination, examining wad done by taking a small sample of normal stool by using stick, by adding a drop of Normal Saline, placed on laced on a glass slide, and after a good mix put carefully the lid of the Caver slide in order to prevent the formation of air bubbles, then examined under a microscope under then they are Checked by taking a small part of a stool sample using a wooden stick by Minor powers (10X) and major powers (40X). For the purpose of viewing the presence or absence of each of the Trophoziot and Cyst as well as Pus cell and red blood cells RBCs, it is also used several private diagnostic tools for ensuring diagnosis amoeba, equipped from (Cer Test Biotec). The Spanish Company so as to determine the Entamoeba.

\section{Isolation of the parasite}

The isolation of amoebas this case of (Entamoeba histolytica) of a stool sample by taking 1 gram of sample and mix it with $3 \mathrm{ml}$ physiological saline, and passed through layers of sterile gauze for the purpose of removing the large slides of the emulsion before adding the sample after isolating amoeba stool added $0.5 \mathrm{ml}$ of emulsion of the sample (media) to the center tube and then incubated tubes and put it in vertical condition in the incubator at a temperature of $37^{\circ} \mathrm{C}$ for 48 hours.

\section{Preparation of Media}

Locke-egg (LE) medium) was prepared, as it is one of the medias, type Xenic culture media culture media for the development of amoeba histolytica, which is (Diphasic media) consists of two phases, is the firstphase solid phase which is down and poses (Slant), the second is the liquid phase, which is (Overlayer) the solid surface is leant. This media was prepared according to the method (Boeck et al., 1925), which consists of two phases: Solid phase: hen's egg was taken, its upper part was fertilized with alcohol ethyl $(70 \%)$ then the egg was broke in a graduated cylinder and mix the contents, taking $45 \mathrm{ml}$ of the content of the egg and added to 12.5 $\mathrm{ml}$ of Lux solution and put the mixture in a blender to that smoothing and became emulsion. Then the emulsion was filtered through several layers of sterile gauze in the flask, funnel, distributed egg emulsion in the pipe laying $20 \mathrm{ml}$ at $5 \mathrm{ml}$ of the tube and the then a slope was made and at heights (1.5-3 $\mathrm{cm})$. By placing them in boiling water bath for 15-20 minutes, after that the pipes were left to cool at room temperature.

\section{Revitalization of bacteria (Lactobacillus spp)}

Ready Lactobacillus spp is activated by suspending the $1 \mathrm{mg}$ of the lyophilized bacteria in $5 \mathrm{~mL}$ of sterile warm water for three hours at a temperature of $37^{\circ} \mathrm{C}$, then add stuck to a beaker containing $50 \mathrm{ml}$ of Mann- Rogosa-Sharper (MRS) broth, and it is incubated under anaerobic conditions at a temperature of $37^{\circ} \mathrm{C}$ for 48 hours, then spread the stuck by sterile carrier with planned and arranged method to the center of MRS for individual places of bacteria, isolates were preserved in a refrigerator at a temperature of $4^{\circ} \mathrm{C}$.

\section{Preparation stuck lactic acid bacteia cells and filtrate}

The developing colonies were transferred on MRS, the solid, into tubes containing $10 \mathrm{ml}$ of broth MRS for the purpose of their revitalization, incubated anaerobically at a 
temperature of $37^{\circ} \mathrm{C}$ for two (24-48) hour (6) and with concentration of $\left(1.5 \times 10^{8}\right)$ cells / $\mathrm{ml}$ by comparing the growth with a tube McFarland (0.5). Then conducted reduction for first half stuck, concentrations were prepared at $\left(1.5 \times 10^{4}, 1.5 \times 10^{2}\right)$ cells / $\mathrm{ml}$ then used to pollinate cultivated parasite.

\section{Preparation of Stuck parasite}

By using Hemocytometer for the purpose of preparing the stuck oftrophoziote of Entamoeba histolytica with concentration of $0.1 \times 10^{6}$ trophozoite/ $\mathrm{ml}$, were prepared of three replicates added $0.5 \mathrm{ml}$ of bacterial Stuck to the tube containing the parasite growth incubated at a temperature $37^{\circ} \mathrm{C}$ heat, then results were recorded after (2448-72) hours. Compared with the negative control (grown without the addition of the parasite stuck) and positive control(grown parasite added to a drug metronidazole).

\section{Mortality rate}

Growth rate of the parasite tested against propolis was calculated from the trophozoite count per ml, mortality rate of E. hitolytica with respect to propolis at various concentrations was obtained as follow (Lwin et al., 2004):

$$
\begin{array}{r}
\text { Mortality rate }(\%)=\frac{\text { Count } / \mathrm{ml} \text { (treated) }}{\text { Count } / \mathrm{ml}(\text { untreated control) }} \times 100-100 \\
\text {. }
\end{array}
$$

\section{Results and Discussion}

Used L.delbruekii and L.fermentum bacteria returnee to the genus Lactobacillus, which were obtained a lyophilic them to test their of $37^{\circ} \mathrm{C}$ where the experiment effectiveness against the parasite inhibitory E. histolytica. After (24-28-72)h incubation at a temperature was performed with three replications for each concentration against parasitic isolation. The results showed that the percentage of viability trophozoite phasefor the condition of the weave when using bacterial cells stuck were directly proportional with increasing concentrations of the bacteria cells stuck L.delbruekii and L.fermentum, The bacteria cells leaky showed less efficient and as shown in (Table $1)$. While the results showed that the highest percentage of the effectiveness of inhibitory was stuck to a concentration of bacteria cells $\left(1.5 \times 10^{8}\right)$ cells $/ \mathrm{ml}$ and by $(97.68 \%)$ after $72 \mathrm{~h}$ incubation, while it was lowest percentage of the effectiveness of inhibitory concentration was when $\left(1.5 \times 10^{2}\right)$ cells / $\mathrm{ml}$ and by $(9.21 \%)$ after 24hincubation as shown in figure (1).The effectiveness inhibitory to a leaky bacteria cells showed less than stuck efficiency with the highest act of inhibitory his results when you focusing $\left(1.5 \times 10^{8}\right)$ cells $/ \mathrm{ml}$ as a percentage of $(35.95 \%)$ after $72 \mathrm{~h}$ incubation and doing less inhibitory at concentration $\left(1.5 \times 10^{2}\right)$ cells / $\mathrm{ml}$ and a percentage of $(1.31 \%)$ after $24 \mathrm{~h}$, and as shown in figure (2). Compared with the negative control and positive control (drug metronidazole), the treatment results also showed stuck of L.delbruekii and L.fermentum occur morphological changes of the trophozoites of E. histolytica was the emergence of cases the decomposition of the plasma membrane and pigmentation abiotic phases when using (dye trypan blue) figure (3) after $72 \mathrm{~h}$ incubation. Statistical analysis showed that there were significant differences in for the value of LSD at the level $\quad(\mathrm{P}<0.05)$ between the concentrations of stuck L.delbruekii and L.fermentum in the number of trophozoites of E. histolytica case as well as the presence of a significant difference to the value of LSD at the level of $(\mathrm{P}<0.05)$ what between the lap times, while no significant differences occur between the lap times of the transaction when the concentration $\left(1.5 \times 10^{2}\right)$ cells / $\mathrm{ml}$ as well as for the treatment of drug metronidazole. 
Table.1 The percentages of viability for E. histolytica trophozoites LEM after treatment with stuck and leaky L.fermentum and L.delbruekii at different concentrations and different times

\begin{tabular}{|c|c|c|c|c|c|c|}
\hline \multicolumn{7}{|c|}{ The percentages of viability for $E$. histolytica trophozoites(\%) } \\
\hline \multirow[t]{2}{*}{ Time } & \multicolumn{2}{|c|}{$24 h$} & \multicolumn{2}{|c|}{$48 \mathrm{~h}$} & \multicolumn{2}{|c|}{$72 \mathrm{~h}$} \\
\hline & stuck & leaky & stuck & leaky & stuck & leaky \\
\hline $1.5 \times 10^{2}$ & 90.78 & 98.68 & 83.88 & 98.02 & $\mathbf{5 3 . 5 7}$ & 97.05 \\
\hline $1.5 \times 10^{4}$ & 82.89 & 94.73 & 68.42 & 90.78 & 11.34 & 81.18 \\
\hline $1.5 \times 10^{8}$ & 72.36 & 86.66 & 57.23 & 77.96 & 2.31 & 64.07 \\
\hline Positive control & \multicolumn{2}{|c|}{40.83} & \multicolumn{2}{|c|}{36.73} & \multicolumn{2}{|c|}{32.22} \\
\hline Negative control & \multicolumn{2}{|c|}{0.00} & \multicolumn{2}{|c|}{0.00} & \multicolumn{2}{|c|}{0.00} \\
\hline
\end{tabular}

Fig.1 The percentages of effectiveness of stuck L.fermentum and L.delbruekii for different concentrations and times on the growth of E. histolytica trophozoites in LEM medium

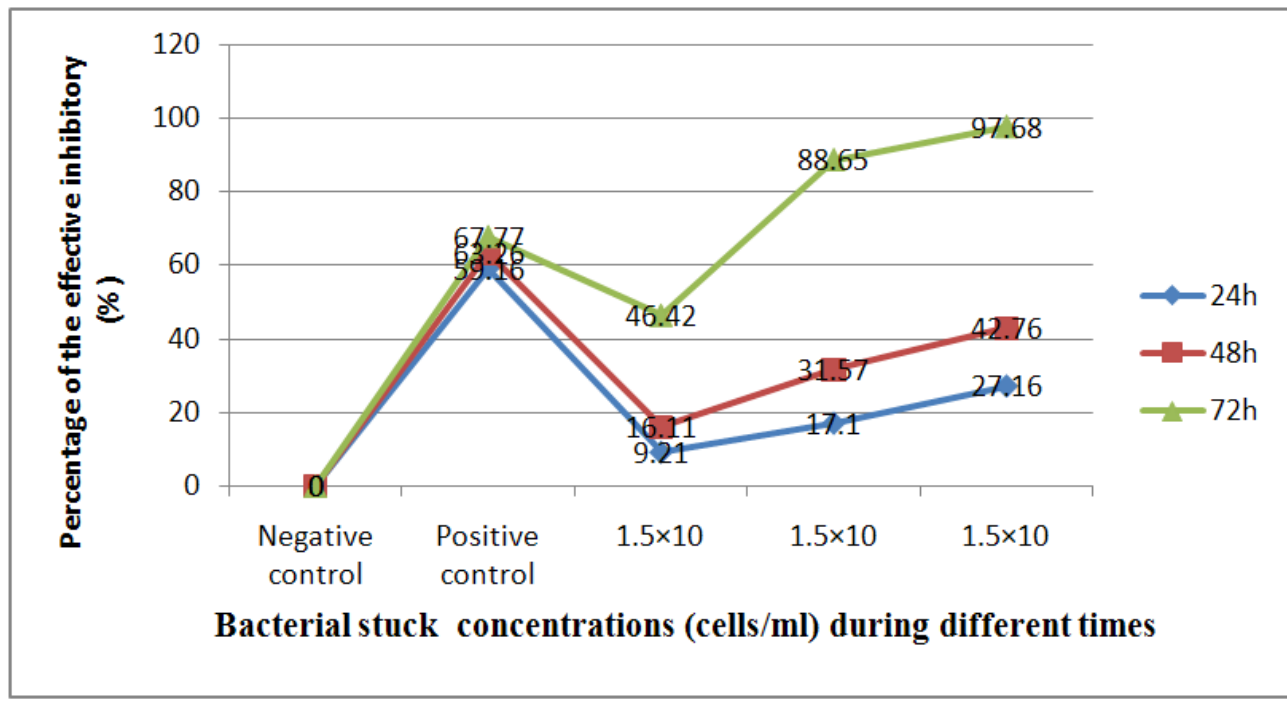

Fig.2 The percentages of effectiveness of leaky L.fermentum and L.delbruekii for different concentrations and times on the growth of E. histolytica trophozoites in LEM medium.

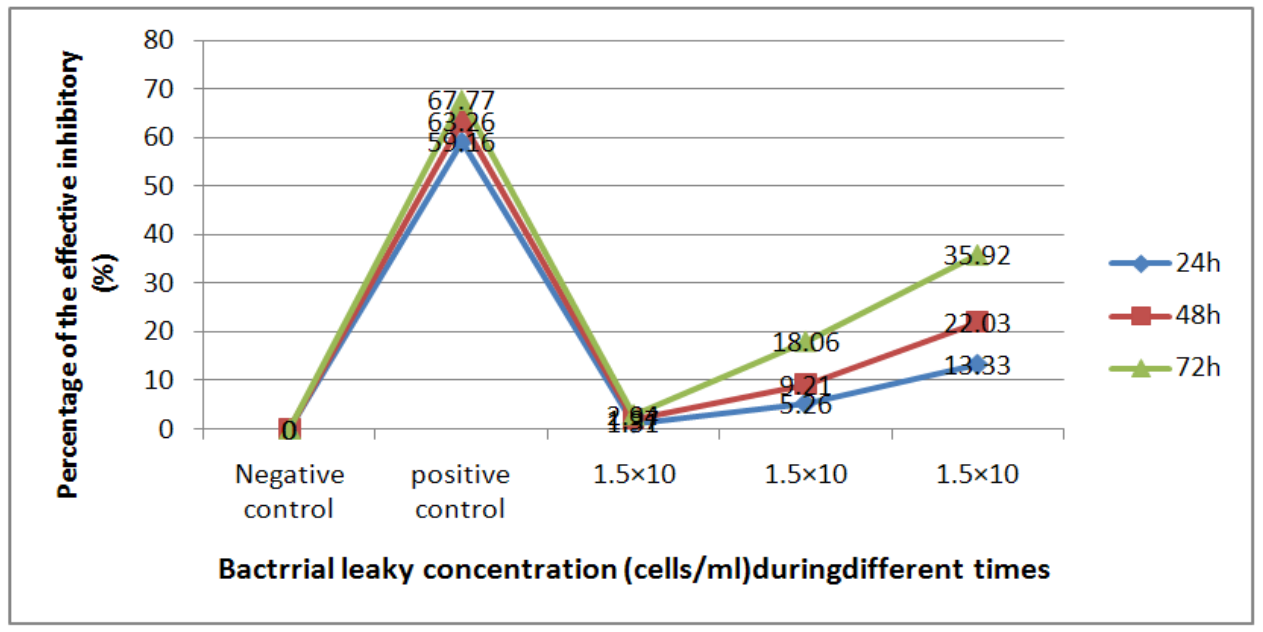


Fig.3 Entamoeba histolytica in culture media (LEM) that treated with (0.5) of the bacteria stuck L.fermentum and L.delbruekii $(1.5 \times 108)(72$ hours $)$. Showed the beginning of the the decomposition of the plasma membrane and colouration abiotic phase (trypan blue dye) (400 X).

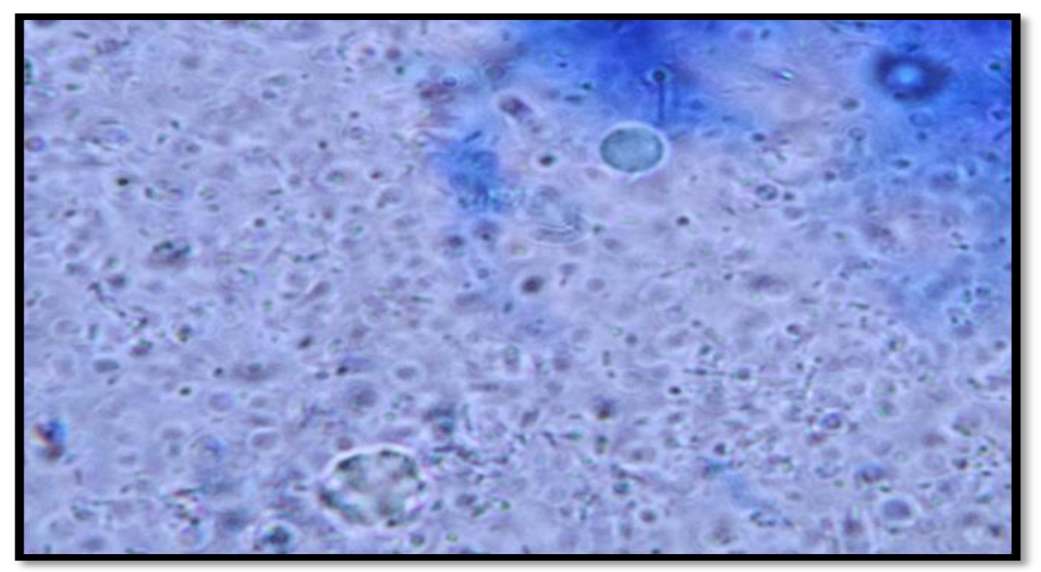

Fig.4 Entamoeba histolytica in culture media (LEM) that treated with (0.5) leaky L.fermentum and L.delbruekii $(1.5 \times 108)(72$ hours). Illustrates cyste phase with binary nucleus (iodine) dye $(1000 \mathrm{X})$

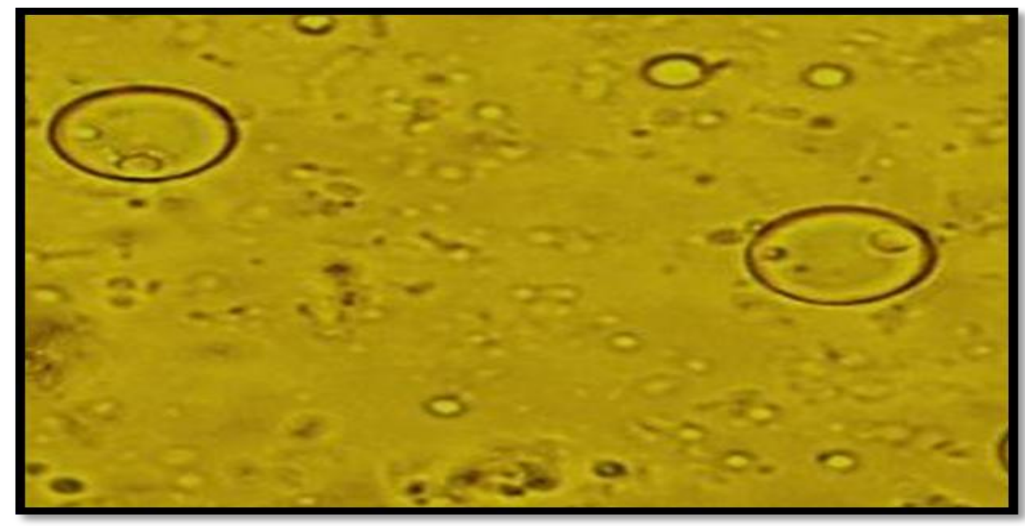

The results showed that were obtained high-efficiency stuck bacteria, lactic acid concentration $\left(1.5 \times 10^{8}\right)$ after $72 \mathrm{~h}$ incubation, to reduce the ratio of trophozite of E. histolytica in vitro, it recorded a therapeutic efficiency was $(97.68 \%)$ of the bacteria L.fermentum and L.delbruekii. This was the highest brought by (Mohamed et al., 2015) in his study of the effect of Lactobacillus salivariuson trophozite of $E$. histolyticain vitro and in vivo by the use of bacteriocins and active substances raised from bacteria, While the results have agreed and approach with brought by (Ahmed, 2012) when using different concentrations of different types of milk on the growth on trophozite of $E$. histolytica in vitro. As it recorded each of cow's milk and soybean milk and coconut milk concentration of $10 \%$ therapeutic efficiency was $(99.7 \%, 99.5 \%$, $96.2 \%$ ), respectively, after $48 \mathrm{~h}$ incubation. Clarify (Ohashi et al., 2003) that Lactoferrin mammals found in milk, which is secreted by the lactic acid bacteria play a role in reducing the infection, because of the ability of inhibition of the enzyme cycteine protease found in bacteria and viruses as well as some parasites. Explained (Ramos et al., 2005) that the cause of this effect is the direct inhibitory damage of the plasma membrane of the bacteria. Lactoferrin is known as a single chain of glycoprotein with a molecular weight of 80KDa and produced from the mammary gland and neutrophil blood cells, and works of iron chelates irregularities outside a cell in the intestinal 
surface this was confirmed (León-Sicairos et al., 2005). This is consistent with the findings of a current study of stuck and filtrates effect of lactic acid bacteria against trophozite of E. histolytica.

\section{References}

Ahmed, Z.A. 2012. Effectiveness of cow's milk and coconut milk and soybean milk on the growth phase feeders for parasitic amoeba condition of (in vitro). Iraqi J., 53(1): 30-39.

Al-Awad, N.J., Whdiiden, H.R., Sallah, M. 2004. The effect of adding two types of stimuli of life locally isolated and its supporting initial stimuli to feed rats for blood lipids. Arabs J., (21).

Bauman, R.W. 2015. Microbiology,4th ed. Pearson Education, Inc. All rights reserved. Manufactured in the United States of America. pp:739-743.

Boeck, W.C., Drobohlav, J. 1925. The cultivation of Entamoeba histolytica. Am. J. Hyg., 5: 371-407.

Forbes, B.A., Saham, S.F., Weissfeld, A.S. 2007. Diagnostic Microbiology. 12th ed. Mosby. Inc. USA.

León-Sicairos, N., Reyes-López, M., Canizalez-Román, A., Bermúdez- Cruz, R.M., Serrano-Luna, J., Arroyo, R., de la Garza, M. 2005. Human hololactoferrin: endocytosis and use as an iron source by the parasite Entamoeba histolytica. Microbiology, 151: 3859-3871.

Lwin, K.M., Oo, M. 2004. In vitro anteamoebicidial activity of "Dysenzi" on Entamoeba histolytica in cultures. FAME Pharmaceuticals Co., Ltd.

Mohamed, S.T., Khalaf, K.J. and Sulaiman, N.M. 2015. Lactobadillus SalivArius
Bacteriocin and supernatant activity against Entamoeba histolytica in vitro and in vivo. British J. Biol. Health and Med. Sci. Res., 3(1): 19-28.

Murray, P.R., Rosenthal, K.S. and Pfaller, M.A. 2013. Medical Microbiology, 7th ed. Saunders, an imprint of Elsevier Inc.pp745- 748.

Ohashi, A., Murata, E., Yamamoto, K., Majima, E., Sano, E., Le, Q., Katunuma, K. 2003. New functions of lactoferrin and beta-casein in mammalian milk as cysteine protease inhibitors. Biochem. Biophys Res. C Commum., 20: 98-103.

Pham, P., Nguyen, H., Hattendorf, J., Zinsstag, J., Dac Cam, P., Odermatt, P. 2011. Risk factors for Entamoeba histolytica infection in an agricultural community in Hanam province, Vietnam. Parasit. Vectors, 4: 102-110.

Ramos, F., Moran, P., Gonzalez, E., Garcia, G., Ramiro, M., Gomez, A., Garcia de Leon, M.C., Melendro, E.I., Valadez, A., Ximenez, C. 2005. Entamoeba histolytica and Entamoeba dispar: Prevalence infection in aural mexican community. Exp. parasitol., 110: 327330 .

Reid, G., Beuerman, D., Heinemann, C. and Bruce, A.W. 2001. Probiotic dose required to restore and maintain a normal vaginal flora. FEMS Immunol. Med. Microbiol., 32: 37-41.

Srivastava, S., Bhattacharya, S. and Paul, J. 2005. Species and strain specific probes derived from repetitive DNA for distinguishing Entamoeba histolytica and Entamoeba dispar. Exp. Parasitol., 110: 303-308.

\section{How to cite this article:}

Zainab Farooq Shafeek and Nada Sabah Ruzzuki. 2016. The Effect of Different Concentrations of the Run and Stuck Bacteria (Lactobacillus fermentum, Lactobacillus delbrueckii) in Trophozoite Growth Entamoeba histolytica in Vitro. Int.J.Curr.Microbiol.App.Sci. 5(7): 924930. doi: http://dx.doi.org/10.20546/ijcmas.2016.507.104 